Ann. Parasitol. Hum. Comp., 1992, $67: \mathrm{n}^{\circ} 2,42-49$.

Mémoire.
Key-words: Rhipicephalus sanguineus. R. pusillus. R. bursa. Dermacentor marginatus. Haemaphysalis punctata. $H$. hispanica. Ixodes ricinus. I. frontalis. I. trianguliceps. I. canisuga. Hosts. Distribution. Ecologic requirements. Seasonal activity. Northeast of Spain.

Mots-clés : Hôtes. Rhipicephalus sanguineus. $R$. pusillus. $R$. bursa. Dermacentor marginatus. Haemaphysalis punctata. $H$. hispanica. Ixodes ricinus. I. frontalis. I. trianguliceps. I. canisuga. Distribution. Nécessités écologiques. Activité saisonnière. Nord-Est de l'Espagne.

\title{
AN ACCOUNT OF THE TICKS OF THE NORTHEASTERN OF SPAIN (ACARINA: IXODIDAE)
}

\author{
A. ESTRADA-PEÑA, J. J. OSÁCAR, C. GORTÁZAR, C. CALVETE, J. LUCIENTES
}

\begin{abstract}
SUMMARY
The tick species commonly collected at the Northeast of Spain are reported in this paper. Data on hosts, temperature and humidity requirements, vegetation relationships, altitudinal distribution, and seasonal activity are included. $R$. sanguineus is commonly collected in areas with Mediterranean vegetation, esteppe, and semidesertic esteppe, ranging from 190 to 1,000 meters above the sea level. $R$. sanguineus is related with sparse vegetal areas, and it is absent from areas with dense shrub or forests of every kind; sometimes, small populations may be collected in ecotones between Pinus spp. and esteppe formations. $R$. pusillus is closely related to areas of Mesomediterranean vegetation, sometimes subordinate to Pinus spp. and Quercus spp. The climate to which the species ally is always of continental type, with a hot and dry summer, and cold winter; although the species is commonly restricted to its main host, Oryctolagus cuniculus, several specimens have been collected from $V$. vulpes. Our data display the clear affinity of I. ricinus to the Supramediterranean vegetation (Aceri-Quercion faginae), places of Quercetum-Buxetum, as well as the Iberian Oromediterranean vegetation (Pinus sylvestris-Buxus sempervirens).
\end{abstract}

Captures are scarce in forest of Fagus sylvatica, but data suggest that the species may be locally common on such places. Climate for the zones of collection of I. ricinus is Atlantic attenuated, with mild summers and humid winters. D. marginatus is strongly related to the xerophilic vegetation, widely spread through the Mediterranean, Supramediterranean, and hill levels, but does not colonize the true Oromediterranean vegetation. In our captures, the species is commonly collected in pubescent oak formations, but it does not penetrate in true forest associations. H. punctata breeds commonly on the Supramediterranean stage, clearly associated to Quercus spp., in wet areas. Both immature and adult stages of $I$. frontalis have been collected in areas of river vegetation (with hot and semi-dry summers, and mild winters, approx. 200 meters above the sea level) and in all the stages of the Mediterranean vegetation (meso-, supra- and oromediterranean). New host records are provided for both $H$. punctata and $I$. frontalis in Spain. Data are also reported for species scarcely collected, as $H$. hispanica, $R$. bursa, I. trianguliceps, and I. canisuga.

\section{RÉsumé : Contribution à l'étude des tiques du Nord-Est de l'Espagne (Acarina : Ixodidae).}

Étude des différentes espèces de tiques présentes dans le NordEst de l'Espagne : hôtes, températures et humidités requises, relations avec la végétation, distributions latitudinales et activité saisonnière. Rhipicephalus sanguineus se capture normalement dans les étages de végétation méditerranéenne, steppe et steppe subdésertique, à une altitude de 190 à $1000 \mathrm{~m}$, dans des zones de végétation ouverte et non dans les zones de buissons denses ou de forêts; de petites opulations peuvent se trouver dans les écotones entre Pinus spp. et steppe. Rhipicephalus pusillus est étroitement localisé dans les zones de végétation mésoméditerranéenne, parfois subordonné à Pinus spp. et Quercus spp. L'espèce est limitée aux régions à climat continental avec étés chauds et secs et hivers froids. L'hôte principal est Oryctolagus cuniculus, accessoirement Vulpes vulpes. Ixodes ricinus est inféodé à la végétation supraméditerranéenne (Aceri-Quercion faginae), zones de QuercetumBuxetum ainsi qu'à la végétation ibérique oroméditerranéenne
(Pinus sylvestris-Buxus sempervirens). Les captures ont été rares dans les bois de Fagus sylvestris, bien que l'on suspecte que l'espèce puisse y être abondante en certains endroits. Ixodes ricinus vit en climat océanique modéré avec étés doux et hivers humides. Dermacentor marginatus est associé à la végétation xérophile des niveaux mésoméditerranéens et supraméditerranéens; il se trouve dans les formations de Chêne pubescent, mais non dans les bois les plus épais. Haemaphysalis punctata est commun dans l'étage supraméditerranéen, associé à Quercus spp. dans les zones humides. Les immatures et les adultes d'Ixodes frontalis se trouvent au voisinage des rivières (avec étés chauds et semi-secs et hivers moyens) à partir d'une altitude de $200 \mathrm{~m}$, dans tous les étages de la végétation méditerranéenne (meso-, supra- et oroméditerranéenne). Les hôtes en Espagne de $H$. punctata et $I$. frontalis sont précisés. Quelques données concernent les espèces rarement capturées $(H$. hispanica, $R$. bursa, I. trianguliceps et I. canisuga).

Unidad de Parasitología. Facultad de Veterinaria. C/Miguel Servet, 177.50013-Zaragoza, Spain.

Accepté le: 19 décembre 1991. 


\section{INTRODUCTION}

Although several papers and notes have been published about the ticks of Spain, with data on new records, hosts, and life cycle under natural conditions (Estrada-Peña et al., 1986, 1987, 1988; Ocabo, 1988) a true compilatory work on hosts, vegetation preferences, distribution areas, and activity period exists only for the ticks of the Salamanca region (Encinas, 1986). Such a kind of revision has been done also for the ticks parasites on bats of Spain (EstradaPeña et al., 1989), although with the limiting factors derived from the dispersion of the records, and the difficulties of collecting ticks on migrating hosts and on their environment (caves).

In France, however, several revisions have been made mainly by Gilot and his coworkers (Gilot, 1985, 1987; Gilot et al., 1973, 1974, 1975, 1977, 1984, 1985, 1989) on the distribution, ecological requirements, and disease relationships of ticks with medical and veterinary interest. This paper wishes to contribute to the knowledge of distribution of ticks in the Northeast of Spain, including data from the captures through 8 years; notes on ecological requirements are extrapolated by the combined usage of collection of the ticks on the vegetation (standard dragging) and on wild and domestic hosts. Data on the life cycle are also obtained from the captures, associated to a network of meteorological stations. As already mentioned, ticks of bats will not be included here, because a revision on that point already exists.

\section{MATERIAL AND METHODS}

THE STUDY AREA

The area surveyed for the present paper is a broad territory, extending from the French-Spanish border at the Pirineos mountains in the northern limit, to the foothills of Iberian mountain system, at south. The Moncayo massif delimits its western limit, the eastern portions corresponding to the Lérida province in Cataluña. The region is a long river valley (the Ebro river) surrounded by mountain spurs at its northern, western, and southern limits. The study area averages $350 \mathrm{~km}$ from north to south, and $280 \mathrm{~km}$ from west to east. Figure 1 shows the position of the whole study zone and the natural regions located on it.

\section{THE VEgetation}

The communities of plants which characterize the Ixodidae biotopes give a general idea of the required ecological conditions for each species. In the results below, we give an approximation to the requirements of the several species, following the main vegetation series, as follows (approximate area of each vegetation series outlined in the Figure 1).

Area 1: Mesomediterranean vegetation with Quercus spp., semi-arid

It occupies the central portion of the study area, at the Ebro mid valley. The natural vegetation is a dense Rhamnus lycioides, with isolated trees $(Q$. coccifera, Juniperus thurifera, J. phoenicea, and Pinus halepensis). The Muelas natural region is mainly com-
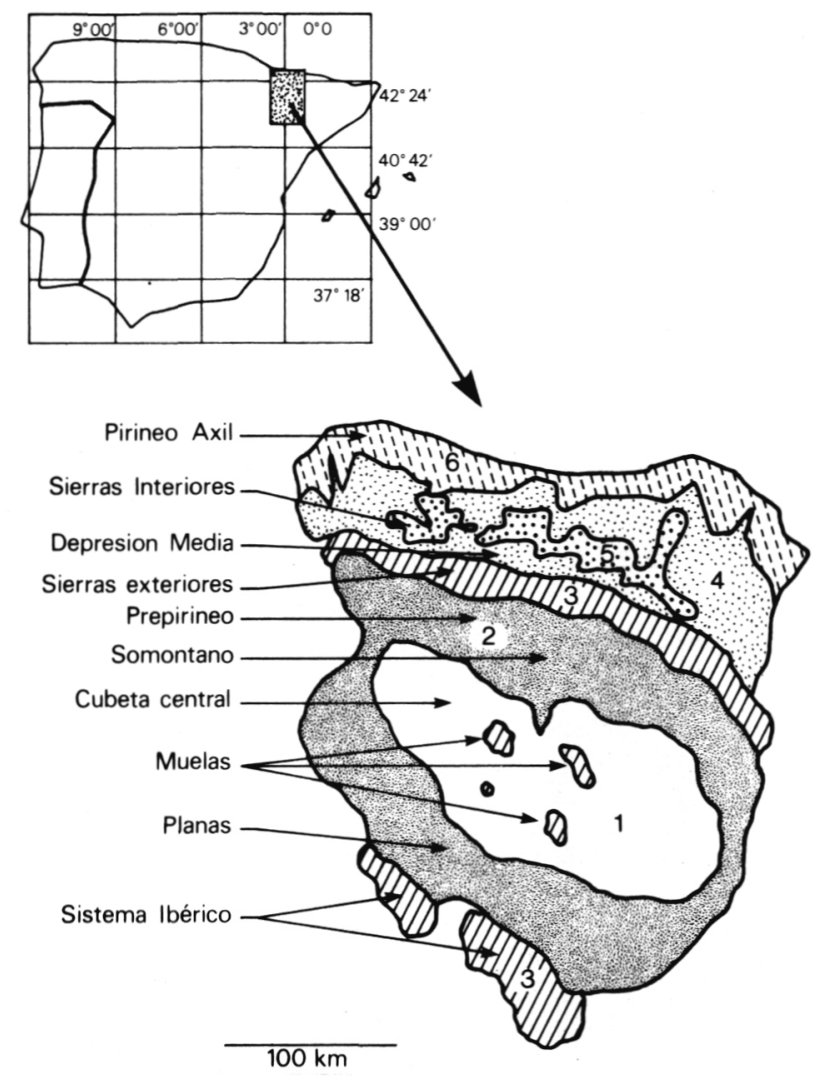

Fig. 1. - Situation in Spain, types of climate and natural regions of the studied area.

posed by $P$. halepensis with a dense shrub, inside the main continental climate, which characterizes the area 1 in the Figure 1.

Area 2: Mesomediterranean vegetation, calcicolous

In this area, $Q$. ilex is replaced with $Q$. rotundifolia, in zones of semidesertic esteppe or true esteppe. There are some places in the region associated with $Q$. lusitanica and Pinus sylvestris.

Area 3: Supramediterranean vegetation with deciduous oaks

It is an association of $Q$. faginea with Acer granatense (AceriQuercion faginae). In the southern portions of the area, it is a Quercetum-Buxetum with Pinus sylvestris. In the most humid zones, with mild winters, Pinus nigra appears as dominant species.

Areas 4 and 5: Iberian oromediterranean vegetation

The zone is truly a mosaic of vegetational conditions. For clarity, we include here only the most relevant vegetal associations. The forests of Pinus sylvestris (area 4 in the Figure 1) represent the biggest portion of the area. They are located on shady parts with late frost in the winter. In the eastern portion of the zone, appear a typical association of pinewood with Buxus sempervirens (Montserrat, 1971). Humid forest (area 5) occupies the northern and western portions of the area. Cold and moist climatic conditions give a favorable habitat for the development of a forest with Fagus sylvatica, Abies spp., and Pinus spp. A clear transition from Fagus to Pinus species occurs from the northwest to the southeast portions of the zone. A vegetation characterized by 


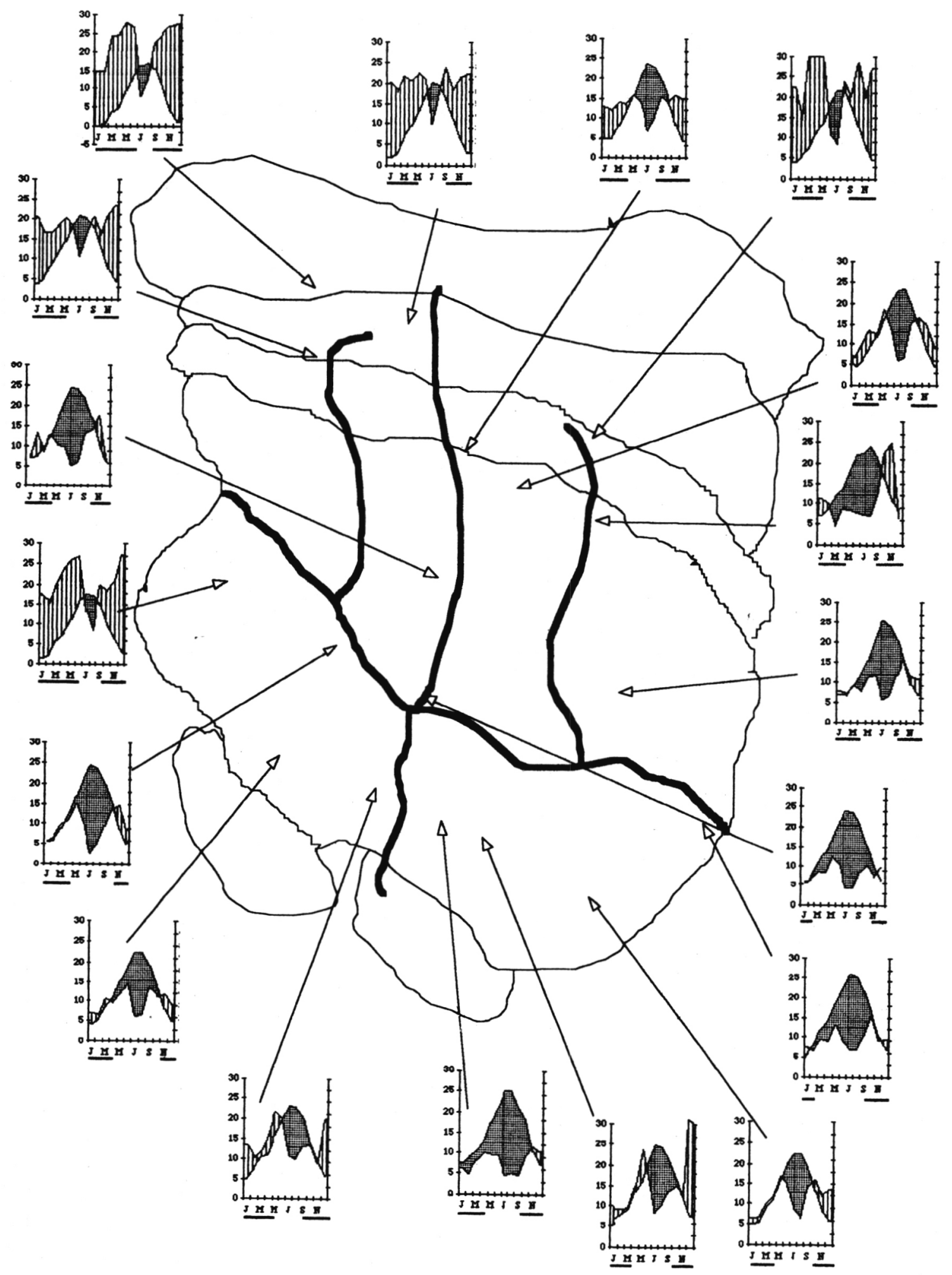

Fig. 2. - The climate for the collection area, as deduced by means of a network of meteorological stations. 
the association of Ulmus, Fraxinus, Acer, and Sorbus, with Quercuspetrea, may be frequent at some zones.

Area 6: Vegetation complex of the north side of the Pirineos.

This vegetation complex of the true mountain biotope is characterized by Mediterranean associations in the eastern side of the area, at 1,600-2,300 meters above the sea level, with Listera cordata and Pinus uncinata. In the central portion of the zone, $P$. uncinata is associated with Mediterranean mountain species, as Thymus, Festuca, and Sideritis. At the highest altitudes, the grass is mainly composed by Carex cervula.

\section{The Climate}

Climate is mainly continental, with a Mediterranean influence, at regions 1 and 2 (Fig. 2); mild winters with late frog and hot summers (maximum temperature in July-August: $47^{\circ} \mathrm{C}$ at some places) characterize the climatic conditions in the Cubeta central region. Climate becomes temperate at higher latitudes. The Sierras Exteriores at region 2 (Fig. 2) has a Submediterranean climate. Sierras Interiores shows an almost Atlantic climate at the western points of the region, with cold winters and humid summers; however, the eastern parts of the zone have a true mesomediterranean climate, with lower relative humidity through the year, and colder winters. Some small valleys extend from the Depresión media region to the Pirineo Axil region, having mild summers and cold, humid winters. Finally, the Pirineo Axil region is the northern limit of the study area, located entirely on the Pirineos mountains, and ranging from 1,600 to 3,000 meters above the sea level. This zone has a typical mountain climate, with snow covering the soil almost the entire year. Southern to the Cubeta central (the true main river valley) several foothills with an attenuated mesomediterranean climate extend. A low relative humidity, a cold winter, and hot summers characterize the Planas area and the Iberian mountain system. Snow is practically absent all over the year at these zones, apart from coldest periods in DecemberJanuary; however, frozen is a common feature from October to mid-April. Figure 2 summarizes the data on the climate by means of ombrothermic curves, obtained from available climatic data at each area, by means of a network of meteorological stations.

\section{Collecting methods}

Ticks were collected between 1982 and 1990, by both standard flagging and captures on domestic and wild hosts. Captures were done through the entire year, although some areas $(i$. e., highest zones of Pirineos mountains) were not visited between November and February because the snow covering the soil. Most captures were done from March to October. Wild mammals were not homogeneously trapped; extensive collections of ticks from rodents, foxes and wild boars were available, while tick captures from Cervus elaphus, Capra hispanica, and Rupicapra pyrenaica were scarce. In the same way, some birds were trapped in abundance (mostly Passeriformes) but other (as bird of prey) are scarcely represented in our collections.

\section{RESULTS AND DISCUSSION}

A total of 11,782 tick specimens is included in this paper. Several species were collected in almost the entire study area, or consistently captured through several years; species included into this group are Rhipicephalus sanguineus Latreille, $R$. pusillus Gil-Collado, Dermacentor marginatus
(Sulzer), Ixodes ricinus Linneo, I. frontalis (Panzer), and Haemaphysalis punctata Canestrini and Fanzago. Data on habitat availability, climate preferences, hosts, and life cycle are provided here for such a group of species. A second group of taxa, however, is yet poorly known; these species are represented by Rhipicephalus bursa Canestrini and Fanzago, Haemaphysalis hispanica Gil-Collado, Ixodes canisuga Johnston, and Ixodes trianguliceps Birula. We include here only some notes on captures and hosts for such a second group of species. Distributional data for each species are included in the Figures 3 to 5, with the map of the study area outlined (main rivers included); captures are represented by shaded squares $(10 \mathrm{~km})$.

\section{1 - Rhipicephalus sanguineus (Fig. 3a)}

The brown dog tick has been commonly collected in areas with Mediterranean vegetation, esteppe, and semidesertic esteppe, ranging from 190 to 1,000 meters above the sea level. $R$. sanguineus is related with sparse vegetal areas, and it is absent from areas with dense shrub of forests of every kind; sometimes, small populations may be collected in ecotones between Pinus spp. and esteppe formations. The species appears under true continental, Mediterranean or semiarid climate; however, no captures were done in termophilic oak forest, although appropriate climatic conditions (as defined by Ocabo, 1988) exist under these vegetal formations. Typical average temperatures at the distribution area of $R$. sanguineus range from 20 to $30^{\circ} \mathrm{C}$ (maximum) in the summer and -5 to $10^{\circ} \mathrm{C}$ (minimum) in the winter; rainfall is lower than $400 \mathrm{~mm}$ in the year at all the collecting localities of $R$. sanguineus. The brown dog tick is particularly well acclimatized to zones with semicold winters and hot, dry summers. Apart from the " wild race " commonly collected as mentioned, $R$. sanguineus seems to be well adapted to the survivor in kennels and/or human buildings, according to data from other authors (Hoogstraal, 1956). Recreational areas in main cities as well as the surroundings of paddocks or animal shelterings, are suitable areas for durable populations of this tick species.

The main host for both adults and immatures is the domestic dog. Several collections have been obtained from feral dogs and foxes. In the central portion of the study area, the species is being progressively adapted to sheep; this kind of parasitation is not observed in other studied areas. Immatures have been extensively collected from the hedgehog (Erinaceus europaeus). Appart from the collection of one larva on Mus spretus, and one male on Otis tarda, rodents and birds does not seem to be suitable hosts for $R$. Sanguineus. Other hosts are: Lepus europaeus, Meles meles, Oryctolagus cuniculus, Equus caballus, and Bos taurus. The species is not a common parasite of the man in our area, as also mentioned by Hoogstraal (1956).

Available data for the cycle under natural conditions sug- 

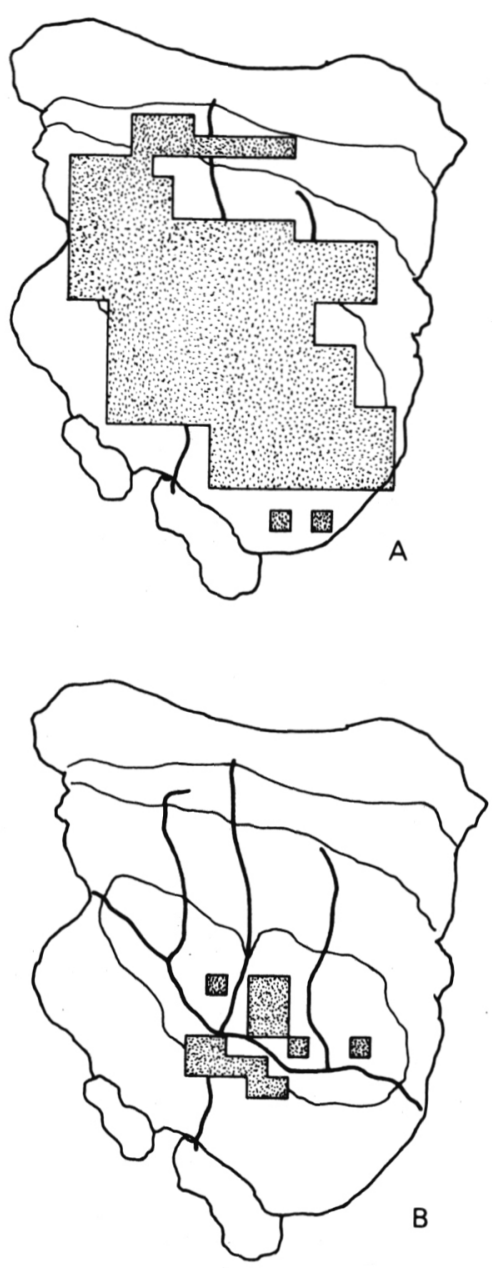

FIG. 3. - The distribution in the Northeast of Spain of Rhipicephalus sanguineus (a) and $R$. pusillus (b). Each square (10 km of side) means for the presence of the studied species into the shaded area.

gest that adults may be active almost in the entire year, providing that adequate conditions are available for active specimens. Samples were not obtained in January and February, although extensive flagging procedures were done at these months. Larvae were collected from June to mid September, and nymphs from mid April to September. Engorged nymphs are the overwintering stage, molting to adults in the spring. At some localities with mild winters, captures suggest the presence of a cohort with unengorged adults as the overwintering stage, because temperatures are enough gentle in autumn to allow the molting of replete nymphs. However, areas with adults as overwintering stages have very hot, dry summers, resulting in a high mortality of spring-derived larvae in summer months; this seems to be the limiting factor in the adoption of such a life cycle by the entire population.

2 - Rhipicephalus pusillus (Fig. 3b)

The distribution of $R$. pusillus is closely related to that of its main host, Oryctolagus cuniculus. This tick is fre- quently associated with Haemaphysalis hispanica and has been consistently collected in all the areas where rabbits commonly breed, in places of mesomediterranean vegetation, sometimes subordinate to Pinus spp and Quercus spp. The climate to which the species ally is always of continental type, with a hot and dry summer, and cold winter; rainfall is restricted to some months in the year (March and October). However, the endophilic status of this species makes these observations as misleading; temperature measurement inside the burrows shows a temperature not higher than $28^{\circ} \mathrm{C}$ in the summer, when outside temperature reaches almost $40^{\circ} \mathrm{C}$.

A great number of specimens have been acquired from the fox, Vulpes vulpes. Foxes are as important hosts for $R$. pusillus as are the rabbits; our captures of adult and young foxes (aged 3-4 weeks old) appoint to the presence of higher populations on foxes than on rabbits. The reasons explaining these observations are not clear; $R$. pusillus is a true endophilic species, and the walking behavior of foxes against the more sedentary habits of rabbits not seems to be the explanation of the higher number of ticks carried by foxes.

As already mentioned, $R$. pusillus is an endophilic species. Many specimens have been collected from the first 2-3 meters of burrows, walking on the sand, and between the pebbles of the lair opening. Adults are active almost the entire year, most collections being carried out from February to October; data from November to January are absent because the erratic behavior of foxes at these dates. Some larvae and nymphs have been trapped on foxes and rabbits from February to March.

3 - Ixodes Ricinus (Fig, 4a)

Although the species is widely distributed in temperate Europe, it shows a patchy distribution in our study area, as a consequence of habitat availability. Studies on this tick species showed the great association of the parasite with deciduous, humid forest (Daniel and Cerny, 1990; Gilot et al., 1989). Our collecting data display the clear affinity of I. ricinus to the Supramediterranean vegetation (Aceri-Quercion faginae), places of Quercetum-Buxetum, as well as the Iberian Oromediterranean vegetation (Pinus sylvestris-Buxus sempervirens). Captures are scarce in forest of Fagus sylvatica, but data suggest that the species may be locally common on such places. Climate for the zones of collection of I. ricinus is Atlantic attenuated, with mild summers and humid winters; mean temperature in July varies between $18-20^{\circ} \mathrm{C}$ and that of January from 3 to $5^{\circ} \mathrm{C}$; the rainfall in the places where $I$. ricinus has been collected is the highest for the entire study area, snow appearing in February for a maximum period of 20-35 days. Captures of $I$. ricinus have been done at altitudes from 800 to 1,400 meters above the sea level.

Cows and sheep are the main domestic hosts for the 


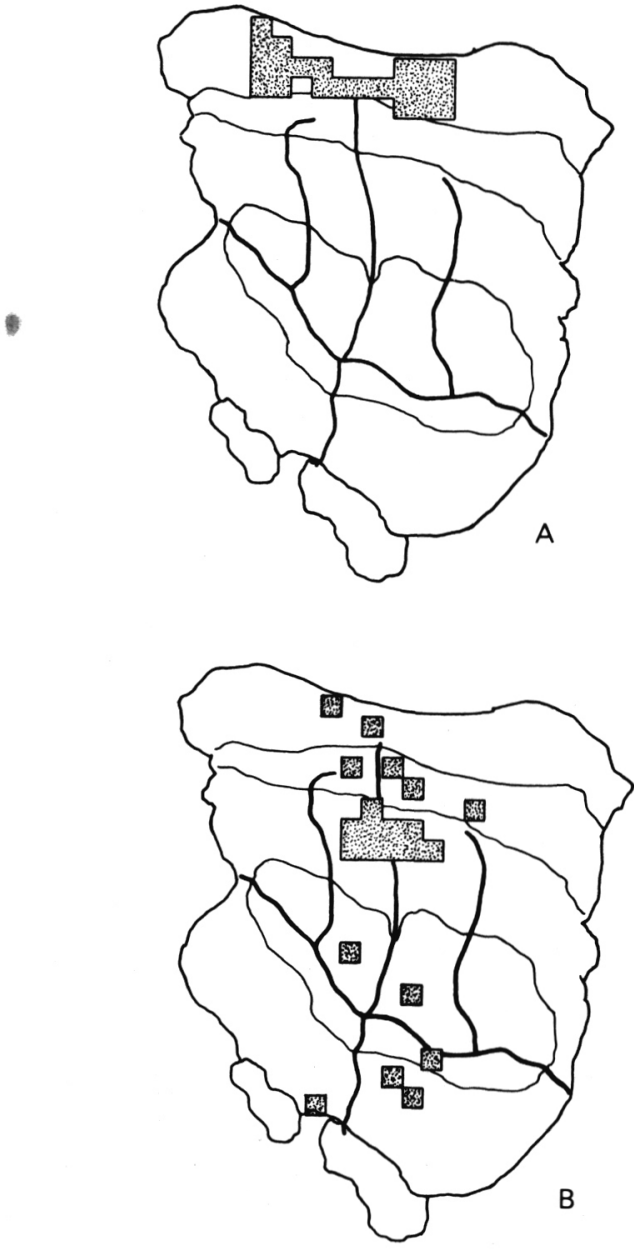

FIg. 4. - The distribution in the Northeast of Spain of Ixodes ricinus (a) and Dermacentor marginatus (b).

adult stages of I. ricinus. Immatures have been repeatedly collected on small mammals, being Clethrionomys glareolus and Apodemus sylvaticus the main hosts for larvae and nymphs. Although we have intensively trapped passeriform birds, only a small number of Turdus spp. and Erithacus rubecula yielded immatures of $I$. ricinus. In the areas of capture of $I$. ricinus, immatures of $H$. punctata occupy the birds as the main tick species; at higher altitudes, I. ricinus is replaced by I. trianguliceps on its small mammal hosts (see below).

\section{4 - Dermacentor marginatus (Fig. 4b)}

The species is strongly related to the xerophilic vegetation, widely spread through the Mediterranean, Supramediterranean, and hill levels, but not colonizes the true Oromediterranean vegetation. In our captures, the species is commonly collected in pubescent oak formations, but it does not penetrate in true forest associations. Scarce collections are also available from xerophilic areas with
Pinus spp., together with a dense brushwood, which delimit its southern border in the study area. The presence of a medium to dense cover seems to be the limiting requisite for the habitat colonization of such as species, the tick being absent from places with a cover so small to provide adequate protection. On the other hand, the species seems to be capable of a broad colonization in altitude, because our captures come from 500 to 1,200 meters.

In our collections, D. marginatus displays a wide capacity to support a vast margin of temperatures and moisture conditions. In such a way, the species colonize not only areas with hot and dry summers (mean temperature in July: $25^{\circ} \mathrm{C}$; mean rainfall in the same month: $20 \mathrm{~mm}$ ) but also wet zones with cold winters (mean temperature in January: $2^{\circ}$ C) D. marginatus has not been collected in wet places where rainfall exceeds $700 \mathrm{~mm}$ in the year; the species is also absent from locations covered by the snow several months in the year. Data from Coty et al. (1986) display a similar picture, the species being considered as a true xerophilic; however, Gilot et al. (1989) mentioned only the xerophilic tendency for the habitat use of the tick.

Wild and domestic Artiodactyls are hosts for the adults of D. marginatus, being Bos taurus, Ovis aries, and Sus scrofa ferus recorded as main hosts for the species. The tick has been scarcely collected on Capra hispanica and Rupicapra pyrenaica. Apodemus sylvaticus is the preferred host for immatures. Extensive collections of small mammals, as Crocidura russula, Microtus spp. and Mus spp. yielded any specimens of $D$. marginatus immatures; also, passeriform birds are not substantial hosts for the species.

The seasonal activity of the adults of $D$. marginatus in the studied area extends approximately from last September to March, when mean temperature falls below $15^{\circ} \mathrm{C}$ and the season of rains starts. In the coldest months, cows are stabled, and the wild boar and the red deer became the main hosts for the adult stage. Available data from small mammal records, pointed to a short activity season for immatures, larvae being active in spring (March-April) and nymphs in the late summer (August-September).

5 - Haemaphysalis punctata (Fig. 5a)

With the exception of Rhipicephalus bursa (mentioned below), $H$. punctata has the most restricted distribution through the collection area, as also mentioned by Gilot et al. (1989) in their studies on ticks of the central parts of France. The species breeds commonly on the Supramediterranean stage, clearly associated to Quercus spp., in wet areas. Our collections come from places with a yearly mean temperature of $10-15^{\circ}$ (maximum in summer: $30^{\circ} \mathrm{C}$; minimum in winter: $-10^{\circ} \mathrm{C}$ ) with a short dry season in July, between 600 and 1,000 meters above the sea level. Rainfall in a year is above $1,000 \mathrm{~mm}$ for the collecting localities of $H$. punctata. Gilot et al. (1989) also mentioned 

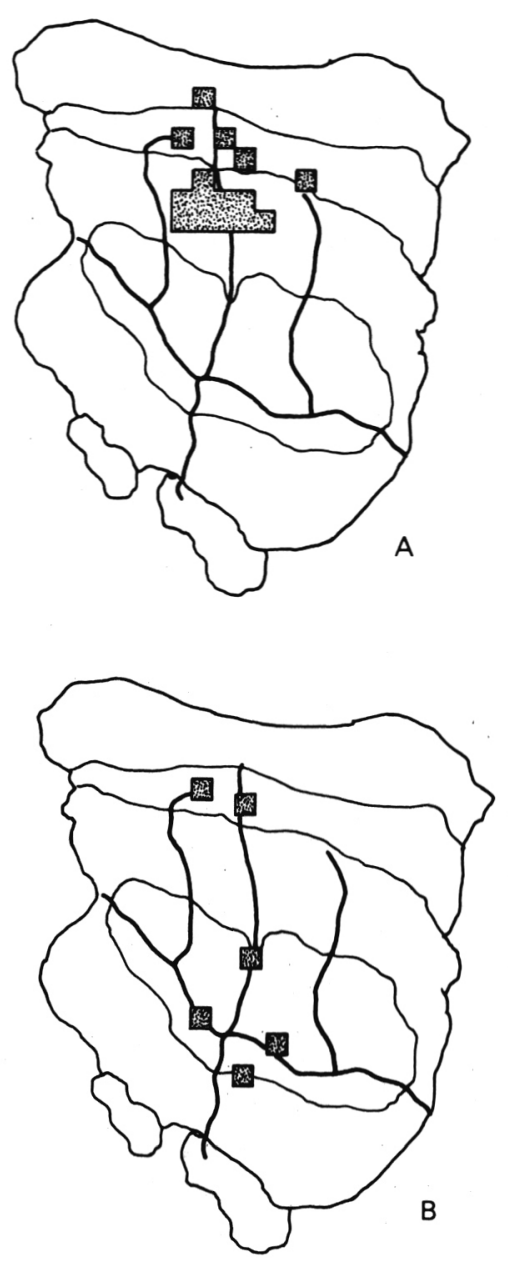

FIG. 5. - The distribution in the Northeast of Spain of Haemaphysalis punctata (a) and I. frontalis (b).

the absence of a true xerophilic preference for $H$. punctata. However, Coty et al. (1986) and Papadopoulos (1990) recorded the xerophilic character of such a tick species.

Domestic ungulates (Bos taurus and Ovis aries) are the only hosts recorded for the adults of $H$. punctata. Captures on wild ungulates (Rupicapra pyrenaica) are scarce; some specimens have been collected on Capra hispanica, but the species is commonly replaced by Rhipicephalus bursa on such a wild host. The species is associated with Dermacentor marginatus along the areas at which the two ticks coexist; sometimes, $H$. punctata and Ixodes ricinus are collected together, but in a lower nomber of cases. Passeriform birds are the main hosts for immatures of $H$. punctata. Larvae and nymphs of the species are commonly collected together with immatures of Ixodes frontalis (see below) on Prunella modularis, Erithacus rubecula, Turdus merula, Parus major, Fringilla coelebs, and Emberiza cirlus.

The adults of $H$. punctata are active and collected on hosts from last summer to the autumn (from last August to October-November); larvae become active and already collected on birds from February to April, and nymphs may be recorded on hosts from last spring (March-April) to first summer (Juny).

6 - Ixodes frontalis (Fig. 5b)

This tick species is the most abundant ixodid on passeriform birds in the study area. The analysis of the captures shows that the species is not fully associated with a definite habitat nor vegetation type, but such an association exists only with appropriate hosts, whatever be the climatic conditions. In such a way, immature and adult stages of I. frontalis have been collected in areas of river vegetation (with hot and semidry summers, and mild winters, approx. 200 meters above the sea level) and in all the stages of the Mediterranean vegetation (Meso-, Supra-, and Oromediterrranean). The species is absent at semiarid habitats, represented by the stage of Quercus coccifera in the studied area.

As mentioned above, Passeriform birds are the typical hosts for this tick species. Recorded hosts for the species are T. troglodytes, Prunella modularis, Erithacus rubecula, Phoenicurus ochurus, Turdus merula, T. philomelos, Sylvia atricapilla, Parus major, Phylloscopus collybita, Fringilla coelebs, and Emberiza schoeniclus. In such a way, I. frontalis prefers as hosts the birds that spend their activity time between bushy vegetation and underwood. Available data suggest that adults are active between last winter (February) and the beginning of the spring (April); larvae become collected on hosts through the spring and first summer, while the activity period for nymphs extends from last summer to the winter.

\section{OTHER SPECIES SCARCELY COLLECTED}

Notes on some species with too few data to complete an overview of its ecological requirements are included here. Such a summary must be considered with caution bearing in mind the scarcity of collections.

\section{1 - Rhipicephalus bursa}

Data for this species are scarce and limited to some little areas with a true mesomediterranean vegetation. Ovis aries and Bos taurus are the only hosts recorded for the adults of the species.

\section{2 - Haemaphysalis hispanica}

This Mediterranean member of the subgenus Rhipistoma is restricted to its host, the rabbit Oryctolagus cuniculus. Several studies carried out on the burrowing coexistence of foxes and rabbits, and the relationships of the tick fauna, show that $H$. hispanica is always absent on foxes, even 
if $R$. pusillus is already collected on fox. In such a way, $H$. hispanica is a true endophilic species commonly collected inside the rabbit burrows. Unlike $R$. pusillus (see above) the species is not abundant in the first meters of the rabbit holes, but it is recorded from the main chamber of the burrow or adjacent tunnels.

\section{3 - Ixodes trianguliceps}

The species is rare and scarcely collected in the studied area. It requires a very humid environment, and our records come from areas with Fagus sylvatica, Abie spp., and Pinus spp., at 1,000-1,500 meters above the sea level. The main limiting factor in the ecological requirements of I. trianguliceps seems to be the relative humidity at the soil level, being absent from the areas that do not fulfill the requirement of a high soil moisture. Small mammals are the only hosts for such a tick species (as reported also by Randolph, 1975). In the studied area, both adults and immatures of $I$. trianguliceps have been captured on Apodemus sylvaticus, Crocidura russula, Clethrionomys glareolus, and Sorex araneus; records on Mus musculus are scarce.

\section{4 - Ixodes canisuga}

We have a few captures of I. canisuga on foxes, collected in the cold season (between October and March). Foxes sustain always an impressive population of ticks, mainly composed by $R$. sanguineus, $R$. pusillus, and Ixodes canisuga. Such a tick fauna varies after the type of vegetation and the season of the year; at dry places, with semiarid and calcicolous mesomediterranean vegetation, $R$. pusillus becomes the main tick species on foxes between February and October, being replaced by $I$. canisuga in the cold season. Captures of foxes in the winter are scarce and data on the evolution of tick fauna between November and January are not available. Gilot and Aubert (1984, 1985) have mentioned that $I$. canisuga is a common species on domestic dogs; however, the dogs did not carry such a tick species in the area where $I$. canisuga is collected on foxes.

\section{REFERENCES}

Coty A., Aeschlimann A., Schneeberger S. : Distribution et fluctuation des populations d'Ixodes ricinus (L.), Haemaphysalis punctata (Can. et Fanz.) et Dermacentor marginatus (Sulzer) (Acarina, Ixodoidea) en Suisse. Bull. Soc. Ent. Suisse, 1986, 59, 139-150.

Daniel M., Cerny V. : Occurrence of the tick Ixodes ricinus L. under the conditions of anthropopressure. Folia Parasitol. (Prague), 1979, 37, 183-186.

Encinas A. : Ticks of the province of Salamanca (central/NW Sapin): prevalence and parasitization intensity in dogs and domestic ungulates. Ann. Parasitol. Hum. Comp., 1986, 61, 95-107.

Estrada-Peña A., Lucientes J., Sánchez C., Gutiérrez J., Ocabo B. : Nuevos datos relativos a la distribución de los Ixódidos en España (II). Rev. Iber. Parasitol., 1987, 46, 431.

Estrada-Peña A., Sánchez C., Lucientes J., Castillo J. A., Gutiérrez J., Galmés M. : Estudio in vitro sobre la mortalidad en las fases de vida libre de diversas especies de garrapatas (Acarina : Ixodoidea). Med. Vet., 1986, 3, 13-25.

Estrada-Peña A., Sánchez C., Ocabo B., Peribáñez M. A. : Un modelo de simulación relativo a la predicción del riesgo de parasitación por garrapatas (Acarina : Ixodidae). Med. Vet., 1988, 5, 305-310.

Gilot B., Aubert M. F. A. : Le parasitisme des carnivores domestiques par les tiques du genre Pholeoixodes (Acarina, Ixodoidea) dans les Alpes françaises et leur avant-pays : bases écologiques. Acta Oecol, oecol. appl., 1984, 5, 355-367.

Gilot B. : Répartition et écologie d'Haemaphylasis punctata (Canestrini et Fanzago, 1877) (Acarina, Ixodoidea) dans les Alpes françaises et leur avant-pays. Rev. Iber. Parasitol., 1985, 45, 25-40.

Gilot B., Aubert M. F. A. : Les Ixodidae (Acariens, Ixodoidea), parasites des carnivores sauvages dans les Alpes françaises et leur avant-pays. Acarologia, 1985, 26, 215-233.

Gilot B., Jarry D., Pautou G., Moncada E. : Biotopes suburbaines à Rhipicephalus turanicus (Acarina : Ixodidae) : étude préliminaire. Ann. Parasitol. Hum. Comp., 1977, 52, 353-362.

Gilot B., Laforge M. L., Toga B., Raoult D. : Relationships between Rhupicephalus genus repartition and mediterranean spotted fever prevalence in France. Rickettsiology: present and future, Palerme (Italy), 21-28 June, 1987.

Gilot B., Pautou G., Immler R., Moncada E. : Suburban biotopes of Dermacentor reticulatus : preliminary study. Rev. Suisse Zool., 1973, 80, 411-430.

Gilot B., Pautou G., Moncada E., Ain G. : Première contribution à l'étude écologique d'Ixodes ricinus (Acarina, Ixodoidea) dans le sud-est de la France. Acta Trop., 1975, 32, 232-248.

Gilot B., Pichot J., Doche B. : Les tiques du Massif Central (France). 1. Les ixodidés (Acariens, Ixodoidea) parasites des carnivores et d'ongulés domestiques sur la bordure orientale du massif. Acarologia, 1989, 30, 191-207.

Gilot B., Robin Y., Pautou G., Moncada E., Vigny F. : Ecology and pathogenic role of Dermacentor reticulatus (Ixodoidea) in southeastern France. Acarologia, 1974, 16, 220-249.

Hoogstraal H. : African ixodoidea. Volume I: Ticks of the Sudan. Research report NM 005 050.29.07, Department of the Navy, Bureau of Medicine and Surgery, 1956, 1,101 p.

Montserrat P. : El ambiente vegetal Jacetano. Pirineos, 1971, 101, 5-22.

Ocabo B. : Estudio de la influencia de la microclimatología sobre la actividad y mortalidad de diversas especies de ixódidos (Acarina, Ixodidae) en condiciones naturales. Tesis Doctoral, Universidad de Zaragoza, 1988, $195 \mathrm{p}$.

Papadopoulos B. : Les tiques des animaux domestiques et les hématozoaires qu'elles transmettent en Macédoine (Grèce). Thèse des Sciences, université de Neuchâtel, 1990, 248 p.

Randolph S. E. : Patterns of distribution of the tick Ixodes trianguliceps on its hosts. J. Anim. Ecol., 1975, 44, 451-474. 